\title{
Changes in community structure of ectomycorrhizal fungi associated with Pinus montezumae across a volcanic soil chronosequence at Sierra Chichinautzin, Mexico
}

\author{
Frédérique Reverchon, María del Pilar Ortega-Larrocea, Jesús Pérez-Moreno, \\ Víctor Manuel Peña-Ramírez, and Christina Siebe
}

\begin{abstract}
Ectomycorrhizal (ECM) communities of Pinus montezumae Lamb. var. montezumae were studied across a volcanic soil chronosequence at Sierra del Chichinautzin, Mexico, to investigate differences in community structure at sites with different soil quality. Study sites were located on volcanic soils of different ages. Both aboveground and belowground fungal communities were compared for 3 years. Species abundance, richness, and diversity were compared among sites. Significant differences were found among the three sites for sporocarp abundance and biomass but not for total ECM root tips. The more diverse sporocarp community was found at the youngest, less fertile site. Dominant species at the sporocarp and ECM morphotype levels differed across the chronosequence. The largest proportion of sporocarp species was siteexclusive, which suggests that aboveground communities depend upon soil conditions. Contrarily, $85 \%$ of ECM morphotypes were present at least at two sites. The poor correspondence between the aboveground and belowground views of the ECM fungal community may be due to differences in sampling methodology and level of identification. Inocybe and Laccaria species were abundant fruiters at all sites, and as multisite fungi, they may be tested for inoculum efficiency to be used in reforestation programs in the surroundings of Mexico City.
\end{abstract}

Résumé : Les communautés d'ectomycorhizes (ECM) du Pinus montezumae Lamb. var. montezumae ont été examinées le long d'une chronoséquence de sol volcanique de la Sierra del Chichinautzin, au Mexique, dans le but d'étudier les différences de structure de communauté entre des stations sur des sols de différentes qualités. Les stations étudiées étaient sur des sols volcaniques d'âges différents. Les communautés fongiques tant souterraines qu'aériennes ont été comparées pendant trois ans. L'abondance, la richesse et la diversité des espèces ont été comparées entre les stations. Il y avait des différences significatives entre les trois stations quant à l'abondance et à la biomasse des carpophores mais le nombre total d'apex racinaires d'ECM était similaire. La communauté de carpophores la plus diversifiée a été observée dans la station la plus jeune et la moins fertile. Les espèces dominantes sur la base des carpophores et des morphotypes d'ECM différaient le long de la chronoséquence. La majorité des espèces de carpophores étaient exclusives à une station, ce qui indique que les communautés aériennes dépendent des conditions du sol. À l'inverse, $85 \%$ des morphotypes d'ECM étaient présents dans au moins deux stations. La faible correspondance entre les deux visions des communautés de champignons ECM est peut-être due aux différences de méthodologie d'échantillonnage et de niveau d'identification. Les espèces d'Inocybe et de Laccaria fructifiaient abondamment dans toutes les stations et, en tant que champignons qui colonisent différentes stations, pourraient être testées pour l'efficacité de leur inoculum dans la perspective d'une utilisation dans les programmes de reboisement aux alentours de Mexico.

[Traduit par la Rédaction]

\section{Introduction}

Large tropical forest areas in the world are distributed on soils of volcanic origin. Studies of volcanic soil chronose-

Received 11 March 2009. Resubmitted 11 September 2009.

Accepted 11 March 2010. Published on the NRC Research Press Web site at cjfr.nrc.ca on 3 June 2010.

F. Reverchon, M.P. Ortega-Larrocea, ${ }^{1}$ V.M. Peña-Ramírez, and C. Siebe. Instituto de Geología, Universidad Nacional Autónoma de México (UNAM), 04510 México D.F., México. J. Pérez-Moreno. Microbiología, Edafología, Colegio de Posgraduados, Campus Montecillo, km 35.5 Carretera MéxicoTexcoco, 56230 Montecillo, México.

${ }^{1}$ Corresponding author (e-mail: mpol@geologia.unam.mx). quences have shown that the progressive weathering of volcanic glass and evolution of physical and chemical soil properties as profile depth, water holding capacity, and nutrient contents generate a gradient in soil development stage and, hence, influence forest growth and productivity (Crews et al. 1995; Jahn and Stahr 1996). In Mexico, the majority of pine forests grow on volcanic soils, which cover 31560 km² (Secretaría de Medio Ambiente, Recursos Naturales y Pesca 2008). Mexico harbours the greatest diversity of Pinus species, with 75 taxa, and the country is the second centre of evolution and speciation of pines worldwide, with $40 \%$ of the recognized species (Perry 1991). Since the survival of pines depends on ectomycorrhizal (ECM) symbiosis (Pérez-Moreno and Read 2004), the studies related to their associated ECM fungal communities are of outstanding im- 
portance. Paradoxically, few studies have examined the distribution of ECM fungal communities in the country (Morris et al. 2008). Most studies on ECM communities have been carried out in temperate regions, and in general, our knowledge of ECM fungi in tropical countries is rather limited.

ECM fungal communities can be described by aboveground sexual structures and underground vegetative ECM root tips. The poor correspondence reported between both makes complementary sampling necessary to get a larger understanding of the whole community (Gardes and Bruns 1996; Horton and Bruns 2001). It can be very complex to plan an adequate sampling that describes the ECM community in a representative manner because of the heterogeneous distribution of ECM species in time and space. Both aboveground and belowground ECM fungal communities are determined by their host as well as by soil characteristics. ECM species distribution in temperate and boreal forests is influenced by various soil factors, such as soil nitrogen content (Lilleskov et al. 2002; Trudell and Edmonds 2004), litter quality (Conn and Dighton 2000), available phosphorus (Twieg et al. 2009), or moisture (Trudell and Edmonds 2004). However, how ECM species are influenced by soil parameters in tropical countries is still unknown, and this information is especially relevant in young tropical volcanic soils. Some of these soils are only $10 \mathrm{~cm}$ deep, and despite this limitation for tree root growth, they are able to support mature forests even when the superficial soil cover limits tree ability for nutrient uptake. The degree of soil development influences tree growth rates (Peña-Ramírez et al. 2009) and may determine the distribution of ECM species as well (Rosling et al. 2003; Baier et al. 2006).

The objective of the present study was to examine abundance, richness, and diversity patterns of ECM fungal communities associated with Pinus montezumae Lamb. var. montezumae across a volcanic soil chronosequence. We hypothesized that the changes in soil quality reported across the chronosequence (Peña-Ramírez et al. 2009) would influence the structure of both aboveground and belowground ECM fungal communities.

\section{Materials and methods}

\section{Study sites}

This study was carried out at the Sierra del Chichinautzin Volcanic Field, in the Trans-Mexican Volcanic Belt, south of Mexico City. This area is composed of numerous monogenetic volcanoes of different ages (Márquez et al. 1999), where soils of distinct stages of development occur on top of the different lava flows. The Sierra del Chichinautzin area, the volcanic soil chronosequence, and the sampling sites have been previously described (see Peña-Ramírez et al. 2009). Briefly, the mean annual precipitation in the region ranges from 1000 to $1200 \mathrm{~mm}$, with a marked seasonality: $80 \%$ of rains occur during the rainy season between June and October. The mean annual temperature varies from 10 to $14{ }^{\circ} \mathrm{C}$ according to the elevation (Silva et al. 1999). The dominant vegetation type is a pine-oak natural forest (Velázquez 1994), with increasing dominance of pine species at higher elevations, especially $P$. montezumae from 2000 m a.s.l. (Perry 1991). A soil chronosequence was established from three volcanoes with contrasting soil proper- ties, resulting from their different eruption times and therefore distinct stages of pedogenesis: Chichinautzin (1835 years BP), Guespalapa (4200 years BP), and Pelado (10 000 years BP). Eruptions have been precisely dated by the radiocarbon method (Siebe et al. 2004). These volcanoes are closely spaced (less than $5 \mathrm{~km}$ ) and are located within the Sierra del Chichinautzin Protected Area (Corredor Biológico de la Sierra del Chichinautzin). One site per volcano was selected to establish the sampling plots. The sites were chosen to avoid any other parameter to counteract the soil effects we wanted to investigate: sampling was performed at the same altitude ( $3100 \mathrm{~m}$ a.s.1.), on slopes of less than $10^{\circ}$ with a south orientation. The stands at the three sites were natural mature pine forests dominated by $P$. montezumae. Since the sites are located within the core zone of the protected area, no forest management is allowed. Forest stands are approximately the same age, since forest turnover does not exceed 150 years - a dendrochronological study (V.M. Peña-Ramírez, personal commmunication, 2008) showed that the average age of $P$. montezumae at Chichinautzin was around 100 years, 105 years at Guespalapa, and 90 years at Pelado. Soil properties at each site have been extensively studied (see Peña-Ramírez et al. 2009) and relevant soil characteristics revealing differences in soil quality across the chronosequence are presented in Table 1.

\section{Sporocarp sampling}

At each site, five sampling plots $(10 \mathrm{~m} \times 10 \mathrm{~m})$ were established around five $P$. montezumae trees, covering a total area of approximately 1 ha (Fig. 1). On behalf of a previous dendrochronological study, pine trees of the same age were selected (around 80 years old), and the distance between selected trees was chosen as large as possible from other ECM host trees to avoid root interactions. Since sites with the same characteristics (altitude, slope, orientation, dominance of 80-year-old $P$. montezumae) were not possible to find within the same volcano, replicates consisted in establishing sampling plots within each site. Sporocarps were collected weekly during the rainy season inside the plots and along transects between them. These transects vary from 30 to $70 \mathrm{~m}$ as our sampling was biased towards the age of host pine trees. We sampled ECM communities for three consecutive years (2005-2007) to reduce the bias caused by annual variability (Koide et al. 2007; Krpata et al. 2007). The weight of fresh sporocarps collected in two of the five plots was recorded weekly to assess aboveground fungal biomass. We considered as ECM species those belonging to ECM genera recognized by Molina et al. (1992). We used both macroscopic and microscopic characteristics for sporocarp identification. Voucher specimens were dried and stored in the Herbarium of the Laboratorio Microcosmos Bioedáfico, at the Instituto de Geología, UNAM (access Nos. MCCECTC001-MCCECTC2000).

\section{ECM root tip sampling}

Since ECM root tips are predominantly found in the soil organic horizon (Baier et al. 2006; Genney et al. 2006), we focused the sampling of soil cores on the Ah soil horizon. Table 1 shows that the thickness of the Ah horizon is quite different according to the soil development stage. At Chichinautzin, the soil cover was highly heterogeneous, with ex- 
Table 1. Soil age, classification, depth, and relevant characteristics of the Ah soil horizon at the three sampling sites (data modified from Peña-Ramírez et al. 2009).

\begin{tabular}{llll}
\hline & Chichinautzin & Guespalapa & Pelado \\
\hline Age of land surface (years BP) & $1835 \pm 55$ & $2835 \pm 75$ to $4690 \pm 90$ & $9620 \pm 160$ to $10900 \pm 280$ \\
Soil classification* & Mollic Leptosol & Lepti-vitric Andosol & Eutrisilic Andosol \\
Soil rooting depth $(\mathrm{cm})$ & $6-35$ & 35.5 & 179 \\
Thickness of the Ah soil horizon $(\mathrm{cm})$ & 6 & 27 & 42.5 \\
$\mathrm{pH}\left(\mathrm{H}_{2} \mathrm{O}\right)^{\dagger}$ & 4.8 & 5.7 & 6.1 \\
Bulk density $\left(\mathrm{g} \cdot \mathrm{cm}^{-3}\right)^{\dagger}$ & 0.56 & 0.86 & 0.61 \\
Carbon $\left(\mathrm{kg} \cdot \mathrm{m}^{-2}\right)^{\dagger}$ & 6.6 & 10.8 & 19.3 \\
Nitrogen $\left(\mathrm{kg} \cdot \mathrm{m}^{-2}\right)^{\dagger}$ & 0.5 & 0.7 & 1.2 \\
Available phosphorus $\left(\mathrm{g} \cdot \mathrm{m}^{-2}\right)^{\dagger}$ & 1.3 & 1.1 & 0.6 \\
Available water $\left(\mathrm{L} \cdot \mathrm{m}^{-2}\right)^{\dagger}$ & 28.2 & 95.4 & 301.6 \\
\hline
\end{tabular}

Note: BP, Before Present. Last eruption date and start of soil formation. The dates correspond to noncalibrated ${ }^{14} \mathrm{C}$ dates. Available P was measured by the Bray method (Bray and Kurtz 1945).

*From World Reference Base 2006.

${ }^{\dagger}$ Calculated for the Ah horizon only.

${ }^{t}$ Calculated for the whole soil rooting depth.

Fig. 1. Size and distribution of plots $(10 \mathrm{~m} \times 10 \mathrm{~m})$ and transects $( \pm 20 \mathrm{~m})$ sampled for sporocarps and ectomycorrhizal (ECM) root tips (cores) of Pinus montezumae at each site.

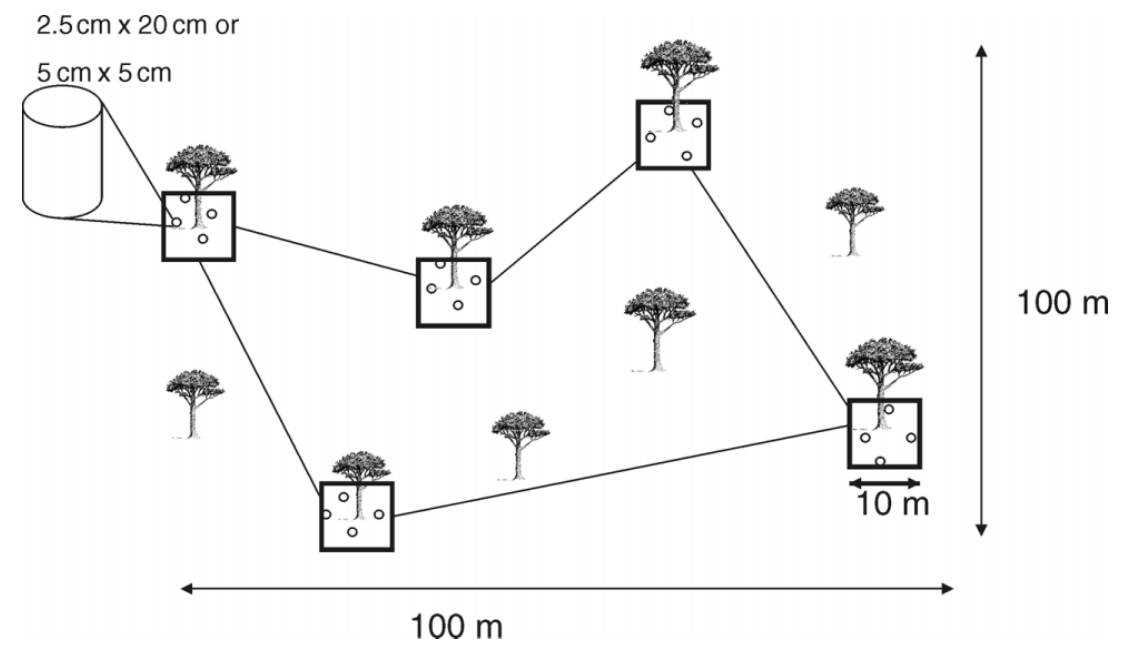

tensive surfaces covered by volcanic rocks and large amounts of stones in the soil profile below $6 \mathrm{~cm}(>80 \%$ stones). At this site, small and wide cores $(5 \mathrm{~cm}$ depth, $5 \mathrm{~cm}$ diameter) were used to sample the Ah horizon (which mostly represents the entire soil profile). At the two other sites, the sampling of mycorrhizas was performed with larger and narrower cores $(20 \mathrm{~cm}$ depth, $2.5 \mathrm{~cm}$ diameter) to cover the same soil horizon (Ah) and to sample the same soil volume at the three sites. All cores were collected at $1 \mathrm{~m}$ from the pine tree, since a high density of ECM fine roots was found in situ from $50 \mathrm{~cm}$ from the trunk (as reported in Luoma et al. 2006). The cores were stored at $4{ }^{\circ} \mathrm{C}$, and $\mathrm{ECM}$ root tips were removed from the cores within 2 weeks, rinsed in water, and sorted by morphotype using a stereo dissecting microscope. The criteria used to differentiate ECM morphotypes were colour, texture, shape, branching pattern, rhizomorph presence, and length and diameter of the unramified ends, following the methodologies described in the Colour Atlas of Ectomycorrhizae (Agerer 1987-2002). In general terms, most ECM root tips presented the characteristic dichotomy of the genus Pinus (Wurzburger et al. 2001).

To determine the sampling effort needed for the study to be representative, we performed a prospective sampling at the Pelado volcano site, at the beginning of the rainy season of the first sampling year. This site was reported to have the most developed soil organic horizon (Peña-Ramírez et al. 2009) and was hypothesized to present the highest ECM diversity (Pérez-Moreno and Read 2000; Twieg et al. 2009). Four samples were collected from the four cardinal points around each tree to account for spatial variability and environmental microsites possibly colonized by different fungi (Bruns 1995). A total of 13 different morphotypes were found in the 20 cores collected for the prospective sampling at the oldest site (Fig. $2 c$, dashed lines). Since most of the morphotypes $(>90 \%)$ were found in the first 15 cores, the actual sampling at the three study sites was thereafter performed with 20 cores, as a larger sampling effort would have had high timeconsuming practical difficulties and presumably low probability to conspicuously increase the observed richness. 
Table 2. Abundance, richness, and diversity of aboveground and belowground ectomycorrhizal (ECM) communities at the three sites.

\begin{tabular}{lllllll}
\hline & $\begin{array}{l}\text { Abundance (no. of } \\
\text { sporocarps collected } \\
\text { per year) }\end{array}$ & $\begin{array}{l}\text { Richness (no. of } \\
\text { sporocarp species } \\
\text { collected per year) }\end{array}$ & $\begin{array}{l}\text { Shannon index } \\
\text { for sporocarps } \\
\text { (per year) }\end{array}$ & $\begin{array}{l}\text { No. of ECM root } \\
\text { tips collected } \\
\text { per year) }\end{array}$ & $\begin{array}{l}\text { No. of ECM root } \\
\text { tip morphotypes } \\
\text { collected per year) }\end{array}$ & $\begin{array}{l}\text { Shannon index } \\
\text { for ECM root } \\
\text { tips (per year) }\end{array}$ \\
Site & $489 \pm 78 \mathrm{a}$ & $64 \pm 4 \mathrm{a}$ & $1.47 \pm 0.026 \mathrm{ab}$ & $687 \pm 258 \mathrm{a}$ & $17 \pm 2 \mathrm{a}$ & $1.04 \pm 0.032 \mathrm{a}$ \\
Chichinautzin & $195 \pm 50 \mathrm{~b}$ & $36 \pm 3 \mathrm{a}$ & $1.30 \pm 0.075 \mathrm{a}$ & $657 \pm 116 \mathrm{a}$ & $12 \pm 2 \mathrm{a}$ & $0.85 \pm 0.105 \mathrm{a}$ \\
Guespalapa & $250 \pm 35 \mathrm{~b}$ & $49 \pm 5 \mathrm{a}$ & $1.49 \pm 0.044 \mathrm{~b}$ & $569 \pm 147 \mathrm{a}$ & $19 \pm 3 \mathrm{a}$ & $1.02 \pm 0.048 \mathrm{a}$ \\
\hline Pelado & 2 & &
\end{tabular}

Note: Significant differences were calculated with Fisher's LSD test $(p<0.05)$.

Fig. 2. Morphotype-sample unit curves for three sampling years ( $\boldsymbol{\Delta}, 2005 ; \boldsymbol{\square}, 2006 ; \boldsymbol{O}, 2007)$. The dashed line represents the data from the prospective sampling. (a) Chichinautzin, young site; $(b)$ Guespalapa, middle-aged site; and (c) Pelado, old site.
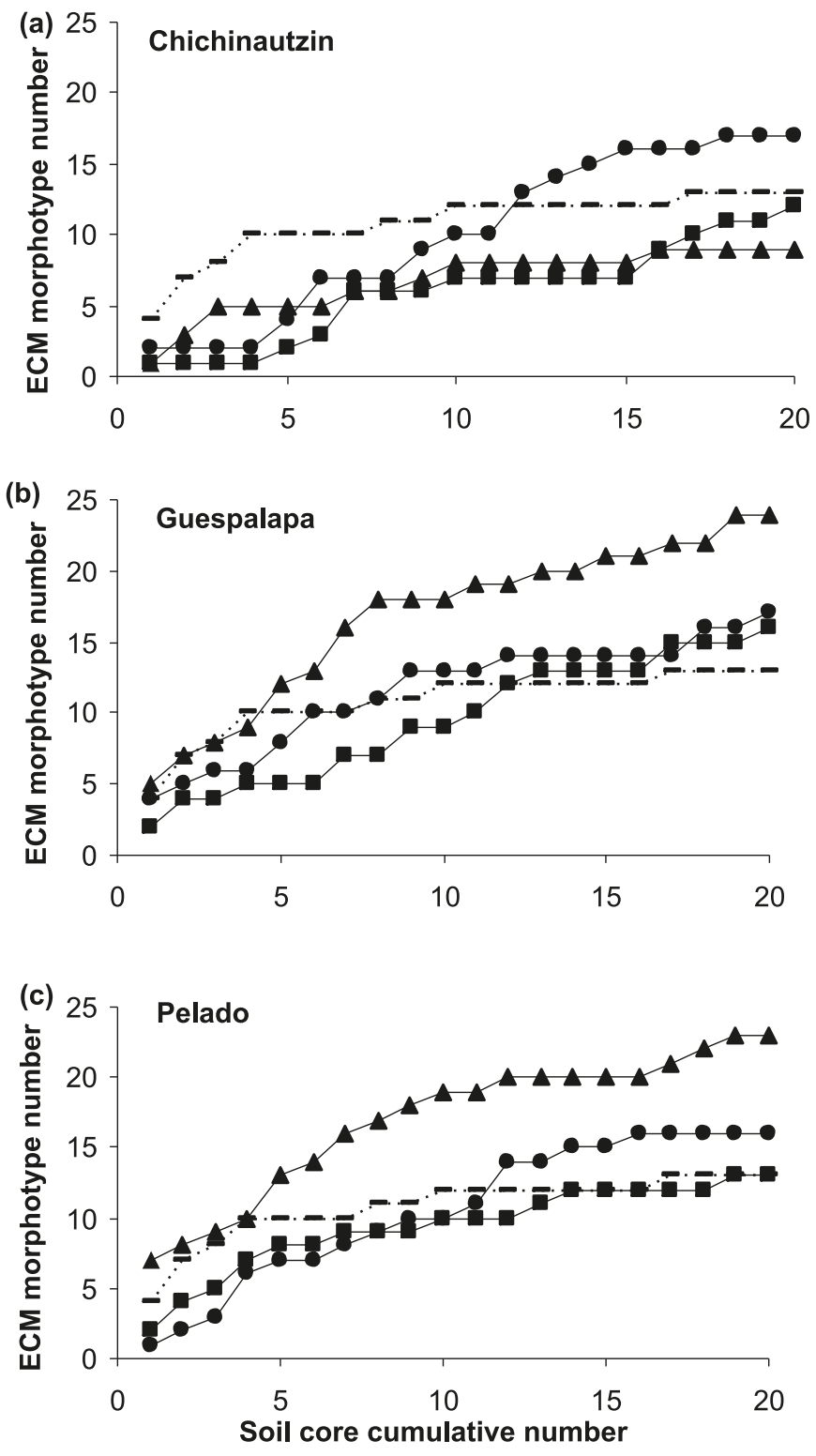

\section{Diversity and statistical analysis}

We used one-way ANOVA and Fisher's least significant difference post hoc test to examine differences in sporocarp and root tip abundance and richness between sites (STATISTICA version 7.0). The analyses were based on the abundance and richness patterns of both belowground and aboveground ECM communities in the five plots established at each site. Species composition of both communities was represented through rank-abundance curves of the 15 more abundant ECM species and morphotypes at each site. Shannon's diversity index (Shannon and Weaver 1949) was used to evaluate the diversity of sporocarp and ECM root tip communities. This index is frequently used to assess ECM diversity (Giachini et al. 2004; Martín-Pinto et al. 2006; Twieg et al. 2009). As it can be problematic to compare species richness and composition between sites (Douglas et al. 2005), the Shannon diversity index is particularly useful when it comes to neotropical forests where few studies have been carried out and comparisons are made difficult.

\section{Results}

Abundance and richness patterns in aboveground and belowground communities

ECM sporocarp production was found to be significantly different across sampling sites, as both sporocarp biomass and abundance differed between sites. Sporocarp biomass (in terms of fresh mass) was significantly larger at the oldest site $(37.3 \pm 0.9$ versus $21.0 \pm 4.7$ and $23.3 \pm 10.5 \mathrm{~g}$ per plot per week according to Fisher's LSD test, $p<0.05)$. On the other hand, ECM sporocarp abundance was significantly larger at Chichinautzin: more than half of the collected sporocarps were found at this site $(52 \%$ of a total of 2795 ECM sporocarps collected during the three sampling years). No significant differences were found among sites for sporocarp richness (Table 2).

At the oldest site where the prospective sampling was performed, at least $87 \%$ of the species richness observed in 20 cores was represented within only 15 cores, independently from the sampling year (Fig. 2c). The number of collected soil cores was found adequate for the 3 years, even though the total number of morphotypes differed. However, at the two other sites, the morphotype-sample unit curves did not level off (Figs. $2 a$ and 2b), and a larger sampling effort would have been needed to ensure the overall species diversity to be considered within the sample at each site. Regarding abundance and richness of the belowground community, and unlike the ECM sporocarp community, neither ECM root tip number nor ECM morphotype number were significantly different between sites (Table 2), despite the existing disparities in soil qualities. 
Fig. 3. Relative abundance of the main ectomycorrhizal (ECM) sporocarp species associated with Pinus montezumae at the three sites - $(a)$ Chichinautzin, young site; $(b)$ Guespalapa, middle-aged site; and (c) Pelado, old site. Asterisks indicate site-exclusive species. Thatched bars represent species common to the three study sites. A. flav., Amanita flavoconia; A. fulv., Amanita fulva; A. musc., Amanita muscaria; A. rube., Amanita rubescens; A. sp.1, Amanita sp. 1; A. hygr., Astraeus hygrometricus; B. chry., Boletus chrysenteron; C. ciba., Cantharellus cibarius; C. cora., Clavulina coralloides; C. anth., Cortinarius anthracinus; C. croc., Cortinarius croceus; C. sp.3, Cortinarius sp. 3; G. flocc., Gomphus floccosus; H. cris., Helvella crispa; H. macr., Helvella macropus; I. cala., Inocybe calamistrata; I. cook., Inocybe cookei; I. fast., Inocybe fastigiata; I. geop., Inocybe geophylla; I. sp.1, Inocybe sp. 1; I. sp.2, Inocybe sp. 2; I. sp.4, Inocybe sp. 4; I. sp.6, Inocybe sp. 6; I. sp.7, Inocybe sp. 7; I. sp.8, Inocybe sp. 8; L. amet., Laccaria amethystina; L. bico., Laccaria bicolor; L. lacc., Laccaria laccata; L. salm., Lactarius salmonicolor; L. deca., Lyophyllum decastes; R. pulv., Russula pulverulenta; T. imbr., Tricholoma imbricatum.
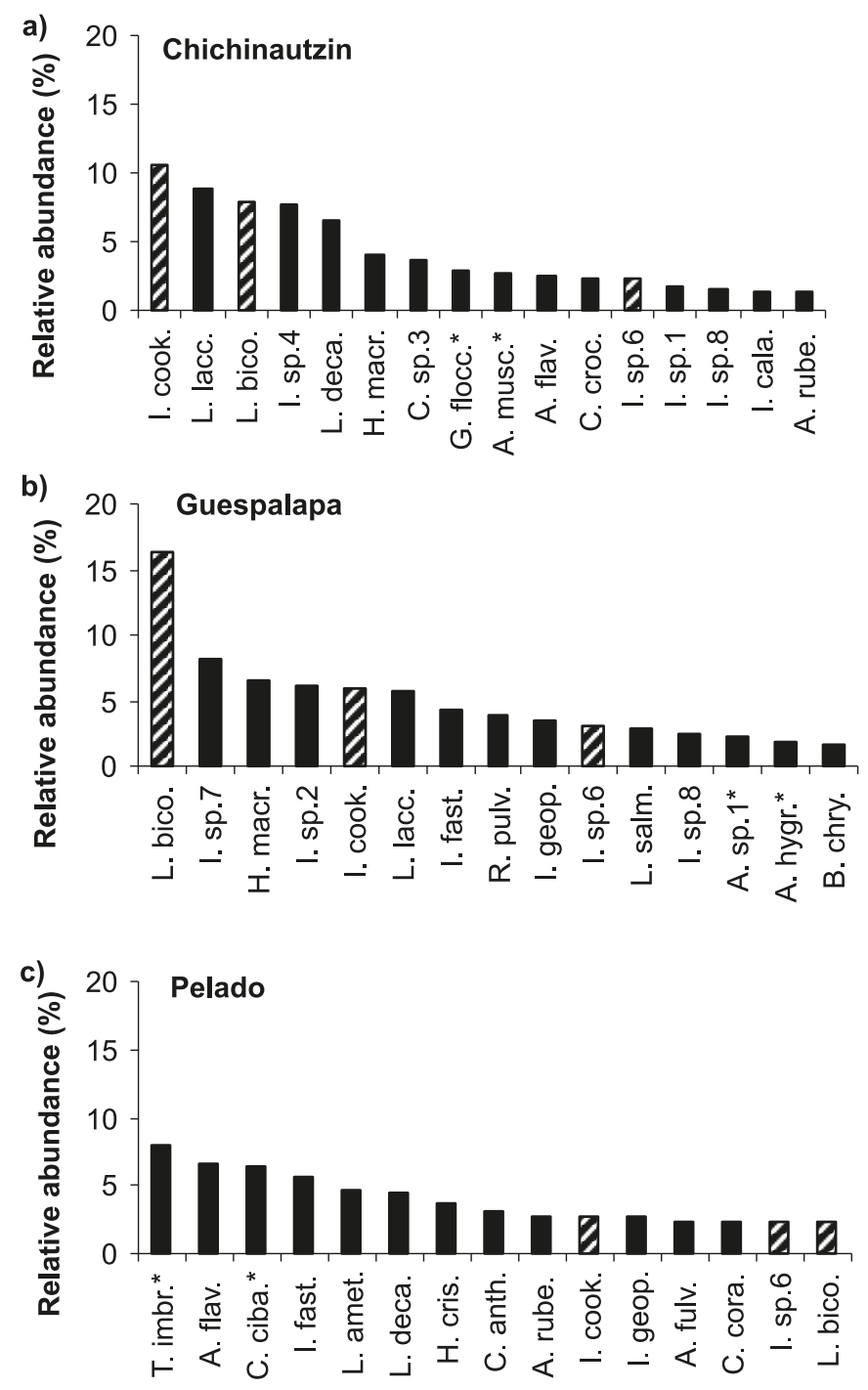

\section{Diversity index and species composition of the ECM communities}

Shannon indexes are presented in Table 2. The lowest diversity was found at the middle-aged site for both aboveground and belowground communities, although the differences were not significant at the belowground level. The lower diversity at this site confirms the abundance and richness patterns described above.

The genera Inocybe and Laccaria were abundant at all sites, accounting for $29 \%$ and $17 \%$ of total abundance, respectively (see supplemental Table $\mathrm{S} 1^{2}$ ). Comparing the relative abundance of dominant sporocarp species (Figs. $3 a-$ $3 c$ ), we observed that three dominant fruiters were common to the three sites: Laccaria bicolor (Maire) P.D. Orton, Inocybe cookei Bres., and Inocybe sp. 6. Some site-exclusive species were also dominant, such as Gomphus floccosus (Schwein.) Singer and Amanita muscaria (L.) Lam. at Chichinautzin; Amanita sp. 1 and Astraeus hygrometricus (Pers.) Morgan at Guespalapa; and Tricholoma imbricatum (Fr.) P. Kumm. and Cantharellus cibarius Fr. at Pelado. The largest proportion of sporocarp species was siteexclusive $(51.6 \%)$ and only 29 of the 153 species $(19 \%)$ were shared among the three sites, which suggests that the species composition of the aboveground ECM community varied according to the site. On the other hand, at the belowground level, site-exclusiveness was lower: only $15 \%$ of morphotypes were site-exclusive, whereas 34 of 40 morphotypes $(85 \%)$ were found at least at two sites (see supplemental Table S2 for morphotype description and Table S3 for morphotype relative abundance ${ }^{2}$ ). The three most abundant morphotypes were morphotypes 30, 15, and 23 and represented $10 \%, 9.4 \%$, and $8.9 \%$ of total abundance, respectively. Three of the dominant taxa were common to the three sites: morphotypes 15, 23, and 24. Site-exclusive morphotypes were found to be abundant only at the oldest site (morphotypes 8, 18, and 28). Nevertheless, morphotype composition varied across the chronosequence (Figs. $4 a-4 c$ ).

The five most abundant sporocarp species represent $41.3 \%$ of total abundance at Chichinautzin compared with $43.2 \%$ at Guespalapa and $31.4 \%$ at Pelado. At the belowground level, the five most abundant morphotypes represent $47.2 \%, 59.9 \%$, and $44.2 \%$ at the young, middle-aged, and old sites, respectively. Dominance patterns are stronger at Guespalapa, for both sporocarp and ECM root tip communities (the most dominant species represent more than $15 \%$ for both communities), owing to the lower abundance and species richness observed at this site.

ECM morphotypes associated with Pinus spp. in tropical countries remain largely uncharacterized. Despite this lack of information, one of the sampled morphotypes was identified as Cenococcum geophilum Fr. (morphotype 1), and others were similar to those described in the genera Laccaria (morphotypes 7 and 11), Tomentella (morphotype 8), Inocybe (morphotype 23), Hebeloma (morphotypes 29 and 37), Lactarius (morphotype 3), and Chroogomphus (morphotype 39 ). The simple features that were used in this study to characterize the ectomycorrhizal morphotypes (colour, size, texture) did not allow a major correlation between dominant sporocarp species and the identified morphotypes, except for

\footnotetext{
${ }^{2}$ Supplementary data for this article are available on the journal Web site (http://cjfr.nrc.ca).
} 
Fig. 4. Relative abundance of the main ectomycorrhizal (ECM) morphotype species associated with Pinus montezumae at the three sites - $(a)$ Chichinautzin, young site; $(b)$ Guespalapa, middle-aged site; and (c) Pelado, old site. Asterisks indicate site-exclusive morphotypes. Thatched bars represent morphotypes common to the three study sites.
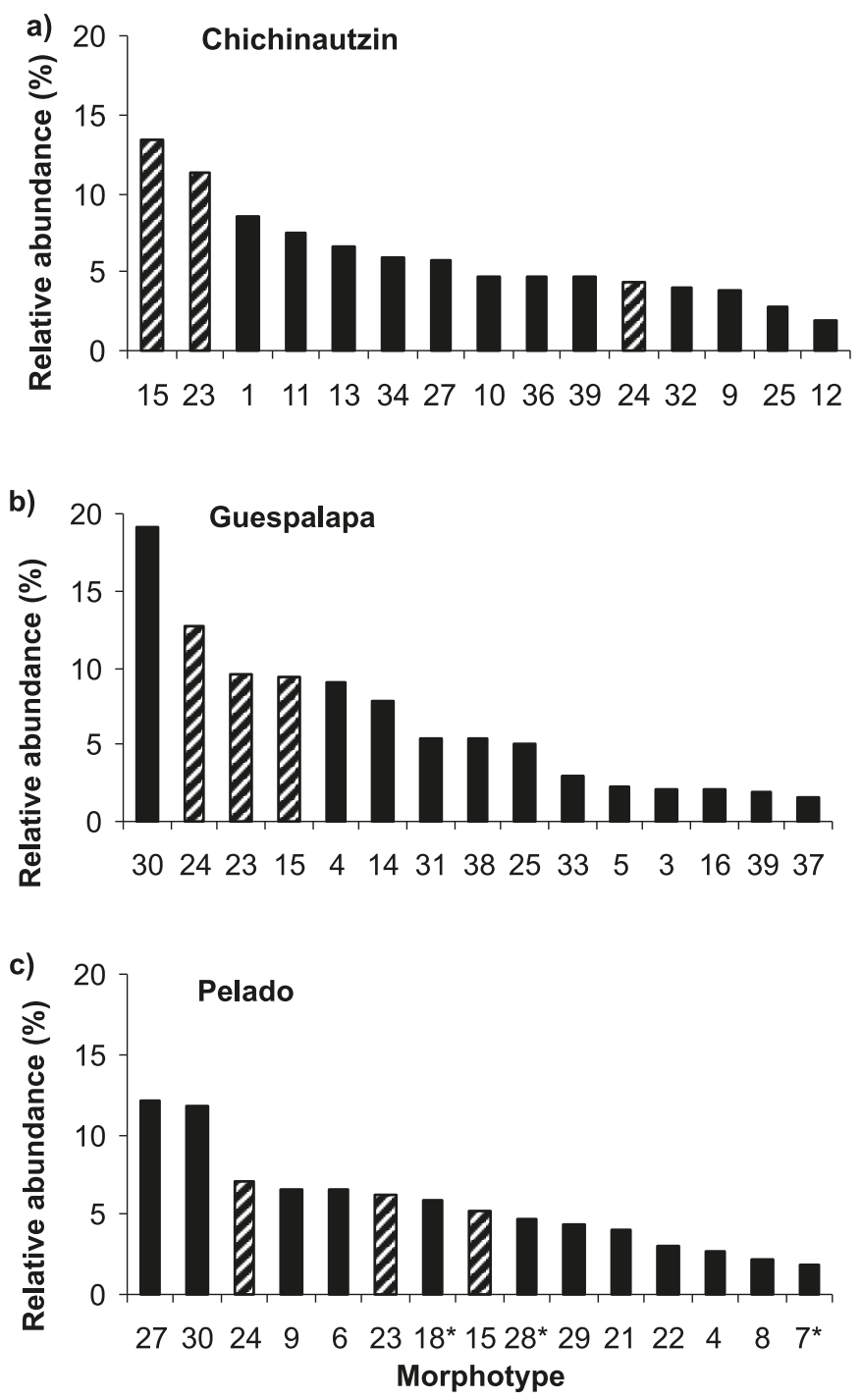

morphotype 23 (Inocybe-like), present at the three sites, which is coherent with the results of the sporocarp community.

\section{Discussion}

\section{Abundance and richness of ECM fungal communities}

We observed differences in ECM sporocarp abundance and biomass among the three sites. Since the species and age of host trees were held constant, soil properties might possibly be the determinants of the differences found in the aboveground community among sites. Our results are consistent with the findings of Trudell and Edmonds (2004) who stated that sporocarp production is influenced by soil properties like moisture and nitrogen content, but they found no correlation between these factors and species richness. The largest sporocarp abundance was found at the youngest site, whereas the largest sporocarp biomass (in terms of fresh mass) was observed at the oldest site. It is important to consider that fresh mass of fruiting bodies could largely depend on the characteristics of dominant species at each site. At the oldest site, the three dominant species (Tricholoma imbricatum, Amanita flavoconia, and Cantharellus cibarius) usually have much larger sizes and weights than those dominant at the two youngest sites (Laccaria spp., Inocybe spp., and Helvella spp.). Additionally, fresh biomass of fungal fruiting bodies, even within the same species, varies with available soil water and previous precipitation events (Luoma 1988). The larger amount of available water at Pelado (Table 1) may explain the larger sporocarp biomass at this site, and dry fungal biomass would have been a more adequate indicator of community structure in this context. The larger mass of fungal fruiting bodies at Pelado may also be related to the total carbon content of the Ah soil horizon at this site (Table 1). According to Tóth and Feest (2007), a high sporocarp production means that fungal species possess enough nutrients and energy to sexually reproduce. This energy could be provided by the host as photosynthates or might be taken from soil carbon when fungal species have the ability to use carbon from other sources (Nara et al. 2003a). On the other hand, the largest sporocarp number was collected at Chichinautzin, where the available phosphorus content of the soil organic horizon was the largest of the soil chronosequence. Further work is needed to establish precise relationships between soil factors and ECM sporocarp number, such as describing the soil properties at each sampling plot to carry out precise correlations.

The simple morphological characterization did not allow us to find significant differences at the belowground level among our study sites, neither in abundance nor in richness, although soil properties across the chronosequence were contrasting. The results of prospective sampling clearly show that sampling effort needs to be determined at each study site separately, as indicated by the discrepancy between the prospective sampling curve and the morphotypesample unit curves of the Chichinautzin and Guespalapa volcanoes (Figs. $2 a$ and $2 b$ ). We carried out the prospective sampling at the oldest site, assuming that root tip abundance would be higher at this site, since the Ah soil horizon was the most developed. However, the root tip abundance was larger, even if not significantly larger, at the youngest site with the driest and shallowest soil, and therefore, ECM root tip richness might have been underestimated at the two youngest sites of the chronosequence. Young volcanic soils have a large spatial heterogeneity caused by the irregularities in the surface of the lava flows (Aplet et al. 1998), which may enhance, to a larger extent than expected, differences in fungal communities (Reverchon et al. 2010). The relatively small water holding capacity and large evaporation rates at this site may be limiting factors for tree growth, and the presence of ECM fungi associated with the roots of $P$. montezumae is therefore crucial for water uptake. Gehring and Whitham (1994) reported that ECM symbiosis was more relevant for plants growing in arid and less fertile soils and suggested, in a following study (Gehring et al. 1998), that ECM communities may be buffered in extreme soil conditions by the energy they received from their hosts. 
The different core proportions used to counteract the different thickness of the soil organic horizon (Ah) between the young site and the oldest ones may also have caused the discrepancy in root tip abundance. The largest root tip number was found at Chichinautzin where only the upper $5 \mathrm{~cm}$ of the soil organic horizon was sampled. The percentage of ectomycorrhizal fine roots decreases with soil depth, and some reports showed that ectomycorrhizas are mainly distributed in the topsoil $(0-5 \mathrm{~cm})$ of organic forest floor and that their quantity decreases drastically below $5 \mathrm{~cm}$ (Hashimoto and Hyakumachi 1998; Baier et al. 2006), although other studies evidence the contrary (Rosling et al. 2003). The largest topsoil $(0-5 \mathrm{~cm})$ volume sampled at Chichinautzin may have increased the number of ECM fine roots and, therefore, may be responsible for the high ECM root tip values found at this site. However, total root tips per core was not significantly different among sites (an average of 48 ECM root tips per core were sampled at Chichinautzin compared with 52 at Guespalapa and 33 at Pelado).

As was previously stated, there is poor correspondence between aboveground and belowground ECM fungal communities (Gardes and Bruns 1996; Horton and Bruns 2001). However, the comparison between the abundance of both communities is made difficult by the differences in the sampling frequency: sporocarps were collected weekly during 3 years, whereas ECM root tips were sampled once a year. Most studies on ECM communities sampled ECM root tips only once a year because of practical limitations (Visser 1995; Gardes and Bruns 1996; Jonsson et al. 1999; Saari et al. 2005; Urban et al. 2008). Sampling intensity was also different, since sporocarps were surveyed in $100 \mathrm{~m}^{2}$ plots, whereas ECM root tips were collected from cores of $98.175 \mathrm{~cm}^{3}$. The volume of soil cores may have been too small to accurately assess the spatial variability of belowground communities and to consider rare morphotypes, and this may have caused the discrepancy found between the larger number of sporocarp species compared with the number of ECM morphotypes. It was previously reported that the distribution of ECM root tips is clustered and that moving the sampling point by as little as $10 \mathrm{~cm}$ can yield large differences in species richness and abundance (Gardes and Bruns 1996; Taylor and Bruns 1999). This patchy distribution makes prospective sampling necessary. In a study on community succession, Twieg et al. (2007) set their sampling effort to 40 soil samples, but despite this large amount of analysed cores, the morphotype-sample unit curves did not level off. They concluded that they did not manage to account for all the species present at their study sites and emphasized the importance of sampling in diversity assessment. Spatial variability of ECM root tips is generally assessed via the collection of various soil cores per plot; however, cores are usually collected once and therefore seasonal and annual variability may not be accounted for.

Temporal variability is also a factor to be considered when sampling ECM fungal communities. Sporocarp and root tip collections were performed in summer, since fruiting in the area only occurs during the rainy season and trees invest a larger part of their carbon flux into roots at this time of the year (Smith and Read 2008). However, some morphotypes might only occur during the dry season (Koide et al. 2007) and therefore will not be represented in this sampling. To reduce annual variability, we meant to achieve exhaustive sampling by repeating both aboveground and belowground samplings for three consecutive years.

The larger species number observed for aboveground communities may also be due to the level of identification: sporocarps can be precisely identified with proper taxonomic training, whereas using simple morphotyping to differentiate belowground ECM species may have led to an underestimation of species richness associated with host roots. The lack of differences among the belowground ECM communities at the three study sites may have been caused by the possible clustering of distinct species difficult to distinguish with morphological criteria only, especially since we did not characterize cellular patterns and structure of fungal mantle. However, morphological methods are necessary for a first differentiation of ECM species to establish dominance patterns in ECM community structure and to carry out further molecular analyses. Molecular techniques are currently applied to identify the main ECM morphotypes sampled at the three sites. It is quite possible that the number of ECM taxa found belowground might increase with the higher resolution of molecular tools. Nevertheless, morphotyping as a first step to determine ECM fungal communities is especially important in tropical countries where knowledge on existing ECM fungal species is still scarce despite the high ECM plant diversity reported in these regions (Morris et al. 2008).

Various studies reported changes in ECM community structure in response to host growth (Visser 1995; Jonsson et al. 1999; Twieg et al. 2007), and it is possible that the resemblance among belowground ECM fungal communities associated with $P$. montezumae in natural mature forests at the three sites is related to the fact that the selected trees were approximately the same age. Since different ECM species have different preferences for the soil environment (Taylor and Bruns 1999; Lilleskov et al. 2002; Trudell and Edmonds 2004), species composition of the ECM community is then more likely to be directly related to soil quality than abundance or richness. Other studies have demonstrated this lack of direct relationship between soil conditions and ECM community abundance and richness (Kernaghan et al. 2003; Twieg et al. 2009) but have found an influence of soil type on fungal community composition (Gehring et al. 1998).

\section{Diversity index and species composition of ECM communities}

Diversity values were found to be significantly different among the three sites for aboveground communities. The values presented in Table 2 are consistent with others reported for Pinus forests. Martín-Pinto et al. (2006) calculated a Shannon index of 1.95 for sporocarp communities in an undisturbed $P$. pinaster forest in Spain. The higher diversity index obtained by these authors compared with our value might be due to the fact they considered saprophyte sporocarps as well. The youngest site of the chronosequence, despite its more extreme soil conditions, was able to sustain the most diverse ECM sporocarp community. However, possibly because of the low level of taxonomic resolution of morphotyping, no significant differences among sites were found at the belowground level. In tem- 
perate regions, diversity of ECM species was found to be positively correlated with soil $\mathrm{pH}$ values (Shaw and Lankey 1994; Baar 1996). In volcanic neotropical areas, our results showed the contrary, since species diversity was higher at the youngest site, which was also the more acidic one. Given that different species of ECM fungi respond differently to $\mathrm{pH}$ and other soil parameters, species composition patterns of the ECM community should be further investigated.

The relative abundance curves (Figs. 3 and 4) show that both aboveground and belowground ECM communities are characterized by a variety of codominant species. This pattern has been previously reported (Visser 1995; Nara et al. $2003 b$ ), with ECM communities usually presenting a high number of rare species and, therefore, little overlap in species composition. Dominance patterns were stronger at the middle-aged site, which is consistent with the smaller abundance and lower species richness observed at this site. The large bulk density and the relatively low nutrient availability at this site may explain the lower diversity at Guespalapa. Dominant sporocarp species at Guespalapa and at Chichinautzin belonged to the genera Laccaria, Helvella, and Inocybe, reported to be "early-stage" species (Nara et al. $2003 a$ ), usually associated to smaller hosts and more extreme conditions. Morphotype 1 (C. geophilum) was found to be abundant at the youngest site. Cenococcum geophilum is reported to be distributed in a wide range of ecosystems and to be resilient to drought stress (Wu et al. 2005), which may explain its presence at Chichinautzin. The abundance of early-stage species at the two younger sites of the volcanic chronosequence may be justified by soil conditions, likely to be stressful for both trees and ECM fungi.

\section{Implications for ECM community studies in neotropical forests}

Given the high diversity and the patchy distribution of ECM fungal communities in coniferous forests (Douglas et al. 2005), it is necessary to determine the needed sampling effort at each site before starting the definitive sampling to account for a representative number of morphotypes. The use of diversity indexes to characterize ECM fungal communities is useful to standardize and compare differences in community structure, since high variation in species abundance and frequency may make any comparison difficult. In this study, sporocarp communities were found to vary among sites, whereas most ECM root tip morphotypes were common to the three sites. Precise identification by molecular methods is recommended, as morphological determination might have underestimated the existent diversity.

The study of ECM community composition generates relevant information for forest conservation at these sites. Fungal genera like Laccaria or Inocybe, which were present at sites with different soil characteristics, could be used as a potential source of ECM inoculum if they proved to be feasibly cultivated and able to successfully establish symbiosis with pine seedlings. Laccaria laccata and Laccaria bicolor have been tested for inoculum potential (Pera et al. 1999; Quoreshi and Timmer 2000; Teste et al. 2004) and have been found to stimulate, in some cases, the growth of conifer seedlings. On the contrary, Inocybe species have been less studied, although this genus is widely distributed from the Arctic to the tropics (Cullings and Makhija 2001). Assessing the ability of these fungal species to form ectomycorrhizas with pine species growing at Sierra del Chichinautzin (such as Pinus leiophylla Schiede \& Deppe, P. montezumae, Pinus patula Schiede ex Schltdl. \& Cham., Pinus pseudostrobus Lindl., Pinus rudis Endl., Pinus teocote Schiede ex Schltdl. \& Cham., and Pinus hartwegii Lindl. at higher altitudes) would improve reforestation strategies in the area (Velázquez 1994; V.M. Peña-Ramírez personal communication, 2008). Our work was conducted within a protected area, but these forests are located in the surroundings of the Mexico City area, where intensive forest exploitation starts to occur. Reforesting with seedlings inoculated with native fungal species adapted to local soil conditions could increase seedling survival in poorly developed soils. This is particularly true where large evaporation rates limit natural forest regeneration, as is the case for the Sierra del Chichinautzin.

\section{Acknowledgements}

This work was supported by a grant from the Programa de Apoyo a Proyectos de Investigación e Innovación Tecnológica (PAPIIT) of Mexico (project Nos. IN225703, IN230507, IN119609). The DGEP (Dirección General de Estudios de Posgrado) provided a fellowship to F. Reverchon for 2 years. We thank the representatives of Topilejo and Cuajomulco communities for authorizing the field work and all the people that helped with the sporocarp sampling during the 3year study. Germán Bonilla helped with the statistical analyses and Kumiko Shimada with the soil characterization.

\section{References}

Agerer, R. 1987-2002. Colour atlas of ectomycorrhizae. EinhomVerlag, Schwäbisch Gmünd, Germany.

Aplet, G.H., Hughes, R.F., and Vitousek, P.M. 1998. Ecosystem development on Hawaiian lava flows: biomass and species composition. J. Veg. Sci. 9(1): 17-26. doi:10.2307/3237219.

Baar, J. 1996. The ectomycorrhizal flora of primary and secondary stands of Pinus sylvestris in relation to soil conditions and ectomycorrhizal succession. J. Veg. Sci. 7(4): 497-504. doi:10.2307/ 3236298.

Baier, R., Ingenhaag, J., Blaschke, H., Göttlein, A., and Agerer, R. 2006. Vertical distribution of an ectomycorrhizal community in upper soil horizons of a young Norway spruce (Picea abies [L.] Karst.) stand of the Bavarian Limestone Alps. Mycorrhiza, 16(3): 197-206. doi:10.1007/s00572-006-0035-z. PMID: 16518613.

Bray, R.H., and Kurtz, L.T. 1945. Determination of total, organic, and available forms of phosphorus in soils. Soil Sci. 59(1): 3945. doi:10.1097/00010694-194501000-00006.

Bruns, T.D. 1995. Thoughts on the processes that maintain local species diversity of ectomycorrhizal fungi. Plant Soil, 170(1): 63-73. doi:10.1007/BF02183055.

Conn, C., and Dighton, J. 2000. Litter quality influences on decomposition, ectomycorrhizal community structure and mycorrhizal root surface acid phosphatase activity. Soil Biol. Biochem. 32(4): 489-496. doi:10.1016/S0038-0717(99)00178-9.

Crews, T.E., Kitayama, K., Fownes, J.H., Riley, R.H., Herbert, D.A., Mueller-Dombois, D., and Vitousek, P. 1995. Changes in soil phosphorous fractions and ecosystem dynamics across a long chronosequence in Hawaii. Ecology, 76(5): 1407-1424. doi: $10.2307 / 1938144$ 
Cullings, K., and Makhija, S. 2001. Ectomycorrhizal fungal associates of Pinus contorta in soils associated with a hot spring in Norris Geyser Basin, Yellowstone National Park, Wyoming. Appl. Environ. Microbiol. 67(12): 5538-5543. doi:10.1128/ AEM.67.12.5538-5543.2001. PMID:11722904.

Douglas, R.B., Parker, V.T., and Cullings, K.W. 2005. Belowground ectomycorrhizal community structure of mature lodgepole pine and mixed conifer stands in Yellowstone National Park. For. Ecol. Manage. 208(1-3): 303-317. doi:10.1016/j. foreco.2004.12.011.

Gardes, M., and Bruns, T.D. 1996. Community structure of ectomycorrhizal fungi in a Pinus muricata forest: above- and below-ground views. Can. J. Bot. 74(10): 1572-1583. doi:10.1139/b96-190.

Gehring, C.A., and Whitham, T.G. 1994. Comparisons of ectomycorrhizae on pinyon pines (Pinus edulis; Pinaceae) across extremes of soil type and herbivory. Am. J. Bot. 81(12): 15091516. doi:10.2307/2445327.

Gehring, C.A., Theimer, T.C., Whitham, T.G., and Keim, P. 1998. Ectomycorrhizal fungal community structure of pinyon pines growing in two environmental extremes. Ecology, 79(5): 15621572. doi:10.1890/0012-9658(1998)079[1562:EFCSOP]2.0.CO;2.

Genney, D.R., Anderson, I.C., and Alexander, I.J. 2006. Fine-scale distribution of pine ectomycorrhizas and their extramatrical mycelium. New Phytol. 170(2): 381-390. doi:10.1111/j.1469-8137. 2006.01669.x. PMID:16608462.

Giachini, A.J., Souza, L.A.B., and Oliveira, V.L. 2004. Species richness and seasonal abundance of ectomycorrhizal fungi in plantations of Eucalyptus dunnii and Pinus taeda in southern Brazil. Mycorrhiza, 14(6): 375-381. doi:10.1007/s00572-0040297-2. PMID:15007709.

Hashimoto, Y., and Hyakumachi, M. 1998. Distribution of ectomycorrhizas and ectomycorrhizal fungal inoculum with soil depth in a birch forest. J. For. Res. 3(4): 243-245. doi:10.1007/ BF02762200.

Horton, T.R., and Bruns, T.D. 2001. The molecular revolution in ectomycorrhizal ecology: peeking into the black-box. Mol. Ecol. 10(8): 1855-1871. doi:10.1046/j.0962-1083.2001.01333.x. PMID:11555231.

Jahn, R., and Stahr, K. 1996. Development of soils and site qualities on basic volcanoclastics with special reference to the semiarid environment of Lanzarote, Canary Islands, Spain. Rev. Mex. Ciencias Geológicas, 13(1): 104-112.

Jonsson, L., Dahlberg, A., Nilsson, M.C., Kårén, O., and Zackrisson, O. 1999. Continuity of ectomycorrhizal fungi in self-regenerating boreal Pinus sylvestris forests studied by comparing mycobiont diversity on seedlings and mature trees. New Phytol. 142(1): 151-162. doi:10.1046/j.1469-8137.1999.00383.x.

Kernaghan, G., Widden, P., Bergeron, Y., Légaré, S., and Paré, D. 2003. Biotic and abiotic factors affecting ectomycorrhizal diversity in boreal mixed-woods. Oikos, 102(3): 497-504. doi:10. 1034/j.1600-0706.2003.12415.x.

Koide, R.T., Shumway, D.L., Xu, B., and Sharda, J.N. 2007. On temporal partitioning of a community of ectomycorrhizal fungi. New Phytol. 174(2): 420-429. doi:10.1111/j.1469-8137.2007. 02000.x. PMID:17388904.

Krpata, D., Mühlmann, O., Kuhnert, R., Ladurner, H., Göbl, F., and Peintner, U. 2007. High diversity of ectomycorrhizal fungi associated with Arctostaphylos uva-ursi in subalpine and alpine zones: potential inoculum for afforestation. For. Ecol. Manage. 250(3): 167-175. doi:10.1016/j.foreco.2007.05.012.

Lilleskov, E.A., Fahey, T.J., Horton, T.R., and Lovett, G.M. 2002. Belowground ectomycorrhizal fungal community change over a nitrogen deposition gradient in Alaska. Ecology, 83(1): 104115. doi:10.1890/0012-9658(2002)083[0104:BEFCCO]2.0.CO;2.
Luoma, D.L. 1988. Biomass and community structure of sporocarps formed by hypogeous ectomycorrhizal fungi within selected forest habitats of the H.J. Andrews Experimental Forest, Oregon. Ph.D. thesis, Oregon State University, Corvallis, Ore, USA.

Luoma, D.L., Stockdale, C.A., Molina, R., and Eberhart, J.L. 2006. The spatial influence of Pseudotsuga menziesii retention trees on ectomycorrhiza diversity. Can. J. For. Res. 36(10): 2561-2573. doi:10.1139/X06-143.

Márquez, A., Verma, S.P., Anguita, F., Oyarzun, R., and Brandle, J.L. 1999. Tectonics and volcanism of Sierra Chichinautzin: extension at the front of the Central Trans-Mexican Volcanic belt. J. Volcanol. Geotherm. Res. 93(1-2): 125-150. doi:10.1016/ S0377-0273(99)00085-2.

Martín-Pinto, P., Vaquerizo, H., Peñalver, F., Olaizola, J., and Oria-de-Rueda, J.A. 2006. Early effects of a wildfire on the diversity and production of fungal communities in Mediterranean vegetation types dominated by Cistus ladanifer and Pinus pinaster in Spain. For. Ecol. Manage. 225(1-3): 296-305. doi:10. 1016/j.foreco.2006.01.006.

Molina, R., Massicotte, H., and Trappe, J.M. 1992. Specificity phenomena in mycorrhizal symbiosis: community-ecological consequences and practical implications. In Mycorrhizal functioning: an integrative plant-fungal process. Edited by M.F. Allen. Chapman and Hall, New York. pp. 357-423.

Morris, M.H., Pérez-Pérez, M.A., Smith, M.E., and Bledsoe, C.S. 2008. Multiple species of ectomycorrhizal fungi are frequently detected on individual oak root tips in a tropical cloud forest. Mycorrhiza, 18(8): 375-383. doi:10.1007/s00572-008-0186-1. PMID:18704515.

Nara, K., Nakaya, H., and Hogetsu, T. 2003a. Ectomycorrhizal sporocarp succession and production during early primary succession on Mount Fuji. New Phytol. 158: 193-206. doi:10.1046/ j.1469-8137.2003.00724.x.

Nara, K., Nakaya, H., Wu, B., Zhou, Z., and Hogetsu, T. $2003 b$. Underground primary succession of ectomycorrhizal fungi in a volcanic desert on Mount Fuji. New Phytol. 159(3): 743-756. doi:10.1046/j.1469-8137.2003.00844.x.

Peña-Ramírez, V.M., Vázquez-Selem, L., and Siebe, C. 2009. Soil organic carbon stocks and forest productivity in volcanic ash soils of different age (1835-30,500 years B.P.) in Mexico. Geoderma, 149(3-4): 224-234. doi:10.1016/j.geoderma.2008.11.038.

Pera, J., Alvárez, I.F., Rincón, A., and Parladé, J. 1999. Field performance in northern Spain of Douglas-fir seedlings inoculated with ectomycorrhizal fungi. Mycorrhiza, 9: 77-84. doi:10.1007/ s005720050003.

Pérez-Moreno, J., and Read, D.J. 2000. Mobilization and transfer of nutrients from litter to tree seedlings via the vegetative mycelium of ectomycorrhizal plants. New Phytol. 145(2): 301-309. doi:10.1046/j.1469-8137.2000.00569.x.

Pérez-Moreno, J., and Read, D.J. 2004. Los hongos ectomicorrízicos, lazos vivientes que conectan y nutren a los árboles en la naturaleza. Interciencia, 29: 239-247.

Perry, J.P. 1991. The pines of Mexico and Central America. Timber Press, Portland, Oregon.

Quoreshi, A.M., and Timmer, V.R. 2000. Early outplanting performance of nutrient-loaded containerized black spruce seedlings inoculated with Laccaria bicolor: a bioassay study. Can. J. For. Res. 30(5): 744-752. doi:10.1139/cjfr-30-5-744.

Reverchon, F., Ortega-Larrocea, M.P., and Pérez-Moreno, J. 2010. Saprophytic fungal communities change in diversity and species composition across a volcanic soil chronosequence at Sierra del Chichinautzin, Mexico. Ann. Microbiol., In press. doi:10.1007/ s13213-010-0030-7. PMID:20351763. 
Rosling, A., Landeweert, R., Lindahl, B.D., Larsson, K.H., Kuyper, T.W., Taylor, A.F.S., and Finlay, R.D. 2003. Vertical distribution of ectomycorrhizal fungal taxa in a podzol soil profile. New Phytol. 159(3): 775-783. doi:10.1046/j.1469-8137.2003. 00829.x.

Saari, S.K., Campbell, C.D., Russell, J., Alexander, I.J., and Anderson, I.C. 2005. Pine microsatellite markers allow roots and ectomycorrhizas to be linked to individual trees. New Phytol. 165(1): 295-304. doi:10.1111/j.1469-8137.2004.01213.x. PMID: 15720641.

Secretaría de Medio Ambiente, recursos Naturales y Pesca. 1998. Mapa de Suelos Dominantes de la República Mexicana. (Primera aproximación 1996). Scale 1:4000 000. México.

Shannon, C.E., and Weaver, W. 1949. The mathematical theory of communication. University of Illinois Press, Urbana, Ill.

Shaw, P.J.A., and Lankey, K. 1994. Studies on the Scots pine mycorrhizal fruitbody succession. Mycologist, 8(4): 172-174. doi:10.1016/S0269-915X(09)80187-0.

Siebe, C., Rodríguez-Lara, V., Schaaf, P., and Abrams, M. 2004. Radiocarbon ages of Holocene Pelado, Guespalapa, and Chichinautzin scoria cones, south of Mexico City: implications for archaeology and future hazards. Bull. Volcanol. 66: 203-225. doi:10.1007/s00445-003-0304-z.

Silva, L., Romero, F.J., Velázquez, A., and Almeida-Leñero, L. 1999. La vegetación de la región de la montaña del sur de la Cuenca de México. In Biodiversidad de la Región de Montaña del Sur de la Cuenca de México. Edited by A. Velázquez, and L.J. Romero. Universidad Autónoma Metropolitana. Secretaría del Medio Ambiente, D.F., Mexico. pp. 65-92.

Smith, S.E., and Read, D.J. 2008. Mycorrhizal symbiosis. 3rd ed. Academic Press, London.

Taylor, D.L., and Bruns, T.D. 1999. Community structure of ectomycorrhizal fungi in a Pinus muricata forest: minimal overlap between the mature forest and resistant propagule communities. Mol. Ecol. 8(11): 1837-1850. doi:10.1046/j.1365-294x.1999. 00773.x. PMID:10620228.

Teste, F.P., Schmidt, M.G., Berch, S.M., Bulmer, C., and Egger, K.N. 2004. Effects of ectomycorrhizal inoculants on survival and growth of interior Douglas-fir seedlings on reforestation sites and partially rehabilited landings. Can. J. Bot. 34: 20742088. doi:10.1139/X04-083.
Tóth, B.B., and Feest, A. 2007. A simple method to assess macrofungal sporocarp biomass for investigating ecological change. Can. J. Bot. 85(7): 652-658. doi:10.1139/B07-068.

Trudell, S.A., and Edmonds, R.L. 2004. Macrofungus communities correlate with moisture and nitrogen abundance in two oldgrowth conifer forests, Olympic National Park, Washington, USA. Can. J. Bot. 82(6): 781-800. doi:10.1139/b04-057.

Twieg, B.D., Durall, D.M., and Simard, S.W. 2007. Ectomycorrhizal fungal succession in mixed temperate forests. New Phytol. 176(2): 437-447. doi:10.1111/j.1469-8137.2007.02173.x. PMID: 17888121.

Twieg, B.D., Durall, D.M., Simard, S.W., and Jones, M.D. 2009. Influence of soil nutrients on ectomycorrhizal communities in a chronosequence of mixed temperate forests. Mycorrhiza, 19(5): 305-316. doi:10.1007/s00572-009-0232-7. PMID:19274470.

Urban, A., Puschenreiter, M., Strauss, J., and Gorfer, M. 2008. Diversity and structure of ectomycorrhizal and co-associated fungal communities in a serpentine soil. Mycorrhiza, 18(6-7): 339354. doi:10.1007/s00572-008-0189-y. PMID:18677625.

Velázquez, A. 1994. Multivariate analysis of the vegetation of the volcanoes Tláloc and Pelado, Mexico. J. Veg. Sci. 5(2): 263 270. doi: $10.2307 / 3236159$.

Visser, S. 1995. Ectomycorrhizal fungal succession in jack pine stands following wildfire. New Phytol. 129(3): 389-401. doi:10. 1111/j.1469-8137.1995.tb04309.x.

World Reference Base. 2006. World reference base for soil resources. 2nd ed. World Soil Resources Reports No. 103. FAO, Rome.

Wu, B., Nara, K., and Hogetsu, T. 2005. Genetic structure of Cenococcum geophilum populations in primary successional volcanic deserts on Mount Fuji as revealed by microsatellite markers. New Phytol. 165(1): 285-293. doi:10.1111/j.1469-8137.2004. 01221.x. PMID: 15720640.

Wurzburger, N., Bidartondo, M.I., and Bledsoe, C.S. 2001. Characterization of Pinus ectomycorrhizas from mixed conifer and pygmy forests using morphotyping and molecular methods. Can. J. Bot. 79(10): 1211-1216. doi:10.1139/cjb-79-10-1211. 